\title{
RURAL ENTREPRENEURSHIP IN ROMANIA
}

\author{
Mihai DINU ${ }^{\text {a* }}$, Bogdan CHIRIPUCI \\ a),b) Bucharest University of Economic Studies, Faculty of Agricultural and \\ Environmental Economics, Bucharest, Romania
}

Please cite this article as:

Article History:

Dinu, M. and Chiripuci, B., 2019. Rural entrepre- Received: 9 September 2019 neurship in Romania. Review of Economic Studies Accepted: 20 November 2019 and Research Virgil Madgearu, 12(2), pp.53-64.

doi: 10.24193/RVM.2019.12.39.

\begin{abstract}
The aim of the research is to determine the degree to which entrepreneurship is present in the rural areas of Romania, as well as to identify the region with the highest entrepreneurship potential in the rural areas. The methodology used was multi-criteria analysis applied to each of the eight development regions in Romania, since they differ in terms of their potential, the purpose being also that of identifying relatively homogeneous units. The analysis revealed that the highest level of the global indicator is to be found in the Sud Muntenia region, which indicates that this region has the highest development potential as far as entrepreneurship is concerned. The research results may represent an important point of view to be included in government strategies for increasing the level of entrepreneurship in each and every development region.
\end{abstract}

Key words: entrepreneurship; rural areas; analysis; employees JEL Classification: $\mathrm{F}_{63}$; M1O; O1O; R11

(C) 2019 Alma Mater Publishing House. All rights reserved.

* Corresponding author. E-mail address: mihai.dinu@eam.ase.ro. 


\section{References:}

1. Agricultural Knowledge and Innovation Systems Towards - an orientation paper on linking innovation and research 2020, 2014.

2. Aprodu, C., 2006. Decalaje agricole și dezvoltarea regională în România. Bucharest: ASE.

3. Alecu, I. and Constantin, M., 2009. Marketingul serviciilor în sistemul producţiei agroalimentare. Bucharest: Ceres.

4. Bujor, M. and Dobre, I., 2012. Economia spaţiului rural. Bucharest: Tribuna Economică.

5. Crosby R.A., Wendel, M.L., Vanderpool, R.C. and Casey, B.R., 2012. Rural Populations and Health: Determinants, Disparities and Solutions. Jossey-Bass.

6. Davidescu, A.A., 2014. Investigating the impact of unemployment rate on the Romanian shadow economy. A complex approach based on ARDL and SVAR analysis. Romanian Journal of Economic Forecasting, o(4), pp.109-127. 